\title{
Effects of temperature on the mussel pump
}

\author{
C. Barker Jørgensen ${ }^{1}$, Poul S. Larsen ${ }^{2}$, H. U. Riisgård ${ }^{3}$ \\ ${ }^{1}$ Zoophysiological Laboratory A, August Krogh Institute, Universitetsparken 13, DK-2100 Copenhagen $\varnothing$, Denmark \\ ${ }^{2}$ Fluid Mechanics Department, Technical University of Denmark, DK-2800 Lyngby, Denmark \\ ${ }^{3}$ Biological Institute, Odense University, Campusvej 55, DK-5230 Odense M, Denmark
}

\begin{abstract}
The nature of the bivalve filter-pump was further elucidated in the mussel Mytilus edulis by investigating effects of temperature on pump and system characteristics. Pumping rates increased with temperature, linearly correlated with the temperature-determined decrease in viscosity of the water. The variation in pumping rate with temperature thus corresponded to the varying viscous resistance to water flow in the canal system of the mussel-pump. The increase in beat frequency of the lateral cilia with temperature therefore had no clear effect on the pumping rate. Also, spawning stimulation of beat frequency was without effect on pumping rates. In the back pressure-flow characteristic of fully open, active mussels, pump pressure at zero flow $\left(\Delta \mathrm{H}_{\mathrm{p}}^{\circ}\right)$ was independent of temperature. Predictions based on the pump modelled as a leaky, viscous, constant-force pump were in good agreement with measured and estimated pump parameters, further supporting the concept of suspension-feeding bivalves as filter-pumps that process the ambient water autonomously - that is, in the absence of physiological mechanisms for regulating water pumping.
\end{abstract}

\section{INTRODUCTION}

The rates at which suspension-feeding bivalves process the ambient water may vary. Much of this variation has been interpreted in terms of physiological regulation. Thus, when laboratory experiments have shown decreasing rates of water pumping with increasing concentrations of algae suspended in the water, this has been interpreted as regulation of filtration rates to maintain constant feeding rates (Winter 1973, Epifania \& Ewart 1977, Palmer 1980, Gerdes 1983, Winter et al. 1984, Sprung \& Rose 1988). In addition, when laboratory experiments have shown low filtration rates at low temperatures, this has been interpreted as an energy-saving adjustment, serving to reduce high costs of filter feeding during winter when concentrations of food particles are low (Newell \& Bayne 1980).

The assumption of physiological regulation of rates of water pumping predominates in the contemporary literature (Borchardt 1985), implying that rate of water pumping at the full capacity of the pump constitutes an extreme. There is, however, evidence that maximum pumping rates actually reflect adaptations that enable suspension feeding bivalves to exploit inherent potentials for growth (Jørgensen 1975a). In young mussels Mytilus edulis, this potential is compatible with a rate of growth of about $10 \mathrm{~mm} \mathrm{mo}^{-1}$ in shell length (Kiørboe et al. 1981, Riisgård \& Poulsen 1981). Such growth rates have only been approached, and not exceeded, in the laboratory, in experiments where groups of young mussels were kept in a through-flow system at concentrations of algae corresponding to high natural concentrations of phytoplankton (Kiørboe et al. 1981, Riisgård \& Randlov 1981). During these experiments, which lasted several weeks to months, the mean rates at which the mussels processed the water were in the upper end of, or above, the range of published values of filtration rates. During the long-term experiments performed by Riisgård \& Randløv (1981) mussels fed at a natural low algal concentration of $3.0 \times 10^{3}$ Phaeodactylum tricornutum cells $\mathrm{ml}^{-1}$, corresponding to about $24 \mu \mathrm{g} \mathrm{C}^{-1}$, remained fully open with extended mantle edges and expiratory siphon. In nature, the potential for growth may be exploited at a concentration of algal cells corresponding to $1.4 \times 10^{4} P$. tricomutum cells $\mathrm{ml}^{-1}$ (Riisgård \& Poulsen 1981, Riisgård unpubl.).

In the laboratory the highest rates of water pumping are found in fully open mussels with extended mantle edges and siphon, whereas reduction of valve gape and retraction of mantle and siphon are correlated with declining pumping rates (Jørgensen et al. 1988). Mussels react to adverse conditions by partial or complete closure of the valves, resulting in reduced or discon- 
tinued pumping of water. The usually low filtration rates found in the laboratory may reflect the high sensitivity of mussels, and other filter-feeding bivalves, to suboptimal conditions, or be due to methodological errors (Famme et al. 1986).

This interpretation of the greatly varying but mostly low rates of filtration that predominate in the literature is consistent with the lack of mechanisms for the control of ventilation of the mantle cavity, as a prerequisite for a regulation of rates of oxygen consumption (Jørgensen et al. 1986b) or feeding (Jørgensen et al. 1986a, 1988).

The present paper aims at further elucidating the nature of bivalve water processing in terms of physiological regulation versus autonomous function of the gill pump. This has been done by studying the effects of temperature on the pump from the level of the pump unit, i.e. the bands of lateral cilia, to the intact organism.

It is generally agreed that the bivalve gills pump water by means of the bands of lateral cilia, which run along the sides of the gill filaments close to the entrance to the interfilament canals. The mechanism by which the active cilia transport water, however, is obscure.

Ultimately, rates of water pumping and beat frequencies of the lateral cilia must be correlated, but the coupling of water transport to ciliary activity is not simple. Thus, it was found that in intact mussels an increase in beat frequency, produced by stimulation with the nerve transmitter serotonin, did not affect the pumping rate (Jorgensen et al. 1988). In the present paper the effect of serotonin on the beat frequency of the lateral cilia was further studied in isolated gill fragments concurrently with studies of the effect of temperature on the ciliary activity.

Studies on the intact organism included determinations of pump characteristics measured individually, as well as measurements of pumping rates in groups of 20 to 30 mussels. The results served to further develop modelling of the pump, as initiated previously (Jørgensen et al. 1986a, 1988).

\section{MATERIAL AND METHODS}

Mussels Mytilus edulis were collected in shallow water at Fyns Hoved, Denmark, and kept in running seawater at the laboratory. Experimental procedures in analysing pump and system characteristics were the same as those adopted by Famme et al. (1986) and Jørgensen et al. (1986a). Pumping rates were determined from the rates at which the mussels cleared the ambient medium at optimal concentrations of suspended algae, Rhodomonas sp. and Dunaliella marina. These cells are 5 to $6 . \mathrm{m}$ in diameter and are com- pletely retained by the gills (Mohlenberg \& Riisgard 1978, 1979). Clearance therefore equals pumping rate.

Analysis of pump and system characteristics was based on the equation established by Jørgensen et al. (1986a):

$$
\begin{gathered}
\Delta \mathrm{H}_{\mathrm{p}}=\Delta \mathrm{H}_{\mathrm{s}}=\Delta \mathrm{H}_{12}+\Delta \mathrm{H}_{\mathrm{f}}+\Delta \mathrm{H}_{\mathrm{ex}} \\
\Delta \mathrm{H}_{12}=\Delta \mathrm{H}_{12}^{\mathrm{o}}\left(1-\mathrm{V} / \mathrm{V}^{\mathrm{o}}\right)
\end{gathered}
$$

where $\Delta H_{p}=$ pressure rise delivered by the pump, measured e.g. as $\mathrm{mm} \mathrm{H}_{2} \mathrm{O}_{;} \Delta \mathrm{H}_{\mathrm{s}}=$ pressure resistance posed by the system; $\Delta \mathrm{H}_{12}=$ back pressure; $\Delta \mathrm{H}_{\mathrm{f}}=$ frictional resistance in upstream and downstream canals: $\Delta \mathrm{H}_{\mathrm{ex}}=$ exit loss: $\Delta \mathrm{H}_{12}^{\mathrm{o}}=$ back pressure at zero pumping rate; $V=$ pumping rate; $V^{\circ}=$ pumping rate at zero back pressure (Fig. 1). System resistances in Eq. (1) were calculated theoretically while the $\Delta H_{12}$ characteristic (Eq. 2) was determined in a set-up which allowed pumping rate to be measured as a function of back pressure above ambient at inlet, imposed at the exit (Famme et al. 1986). The pump characteristic was then inferred from Eqs. (1) and (2). For further details, see Jorgensen et al. (1986a, 1988).

The effects of temperature on pump characteristics and filtration rates were studied both in mussels kept at the temperature of acclimatization in nature, ranging from 6 to $17^{\circ} \mathrm{C}$, and at abruptly changed temperatures, where the temperature was controlled by means of cooling with ice bags or heating with an electrical heater.

The relationships between effects of temperature and serotonin concentration on the beat frequency of the lateral cilia were studied on gill fragments of the mussel Modiolus modiolus, collected in the Kattegat, Denmark, at 11 and $21^{\circ} \mathrm{C}$ with serotonin added to the medium at concentrations ranging from $10^{-7}$ to $10^{-5} \mathrm{M}$. The effect of serotonin and temperature on beat frequency was also estimated in intact mussels by measuring on gill fragments immediately after their excision. The frequencies were measured stroboscopically under the microscope.

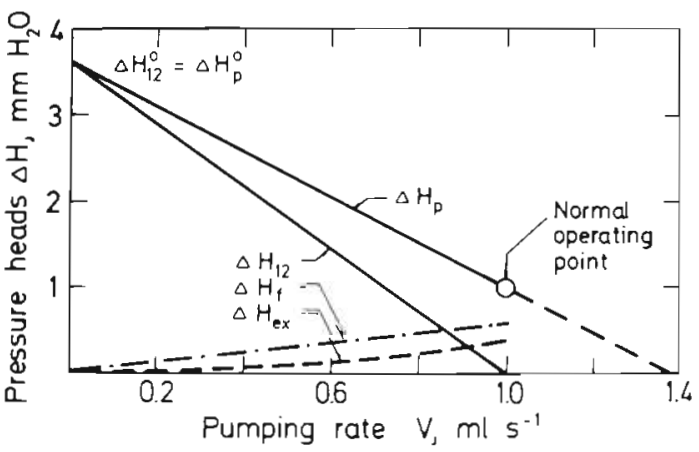

Fig. 1. Mytilus edulis. Schematic characterization of the mussel pump. $\Delta H_{f}$ : head-flow characteristic for friction; $\Delta H_{e x}$ : for exit flow; $\Delta H_{12}$ : for back pressure; $\Delta H_{p}$ : for pump pressure. $\Delta \mathrm{H}_{12}^{\circ}=\Delta \mathrm{H}_{\mathrm{p}}^{\circ}$ is pump pressure at zero flow 


\section{RESULTS AND DISCUSSION}

\section{Temperature and rate of water pumping}

The effects of rapid changes in temperature on the mean rates of water processing in mussels acclimatized to the seasonally varying temperatures were studied in 3 experiments, one from February in mussels acclimatized to $6^{\circ} \mathrm{C}$, one from May in mussels acclimatized to $7.5^{\circ} \mathrm{C}$ and one from June in mussels acclimatized to $12^{\circ} \mathrm{C}$; the temperatures were measured at the collection site (Fig. 2). The temperature ranges adopted in the experiments were those tolerated by the mussels, that is, within which they remained fully open, indicating that they pumped water at the capacity of the pump. It may be seen that in the cold-adapted mussels in February the upper temperature tolerated was $16^{\circ} \mathrm{C}$, compared with $22^{\circ} \mathrm{C}$ in June. In the lower range, the cold-adapted mussels tolerated temperatures approaching zero, whereas the $12^{\circ} \mathrm{C}$ adapted mussels began to reduce the valve gape or to close at 4 to $5^{\circ} \mathrm{C}$.

The relationships between temperature and pumping rate, as based on 17 and 25 measurements, respec- tively in February and June, tended to be curved, consistent with the finding that in the February experiment the slope of linear regression of pumping rate on temperature from 2 to $6^{\circ} \mathrm{C}$ was significantly higher than from 6 to $16^{\circ} \mathrm{C}(\mathrm{p}<0.02)$

Part of the variation in pumping rate with temperature may be due to changes in the viscosity of the water which affects the resistance to water flow in the canal systems of the mussel-pump. This contribution may be estimated from the relationship between pumping rate and viscosity. The regression parameters, listed in Table 1, indicate a close inverse linear relationship between pumping and viscosity. Fig. 3, moreover, indicates that this relationship encompasses the whole temperature range within which the mussels remained fully open. Thus, little room was left for other factors than viscosity in influencing the rate of water pumping, such as the frequency of beating of the lateral cilia. As discussed below, ciliary beat frequencies vary with temperature, implying that substantial changes in beat frequencies of the lateral cilia have no obvious effect on the pumping rate.

The most extensive previous study of the effect of temperature on rate of water pumping in a filter-feed-

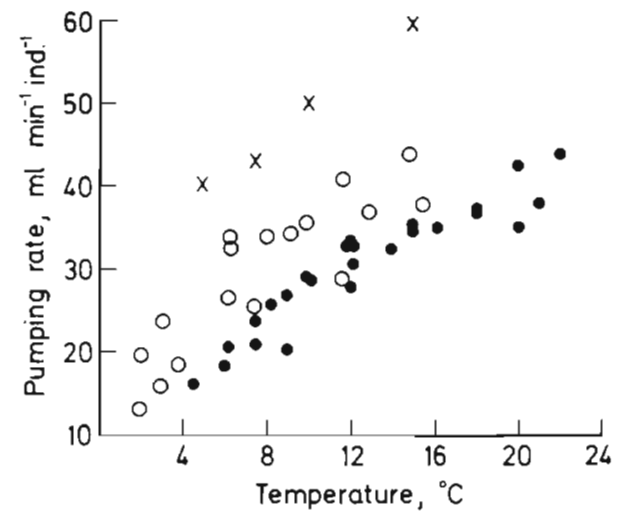

Fig. 2. Mytilus edulis. Relationship between temperature and clearance of algal cells (= pumping rates) in groups of acclimatized mussels at different times of the year. (0) February, 25 mussels, $31 \pm 0.7$ (SD) $\mathrm{mm}$ in length, acclimatized to $6{ }^{\circ} \mathrm{C}_{i}$ (x) May, 20 mussels, $39 \pm 2.0 \mathrm{~mm}$, acclimatized to $7.5^{\circ} \mathrm{C}$; June, 30 mussels, $29 \pm 2.6 \mathrm{~mm}$, acclimatized to $12^{\circ} \mathrm{C}$

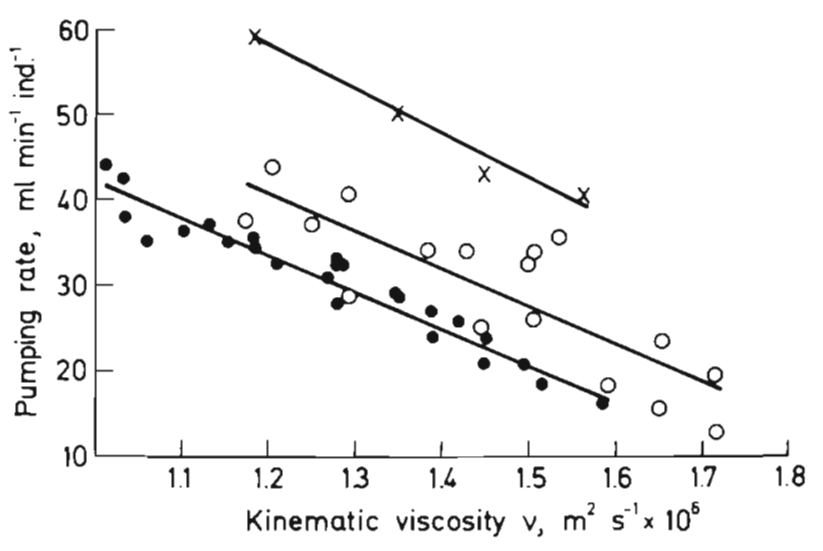

Fig. 3. Mytilus edulis. Relationship between pumping rates and temperature-dependent kinematic viscosity $v$ of seawater in the groups of mussels shown in Fig. 2, using the same symbols

Table 1. Mytilus edulis. Linear regression of algal (Dunaliella manina) clearance (= pumping rate), $\mathrm{V},\left(\mathrm{ml}^{\mathrm{min}} \mathrm{m}^{-1}\right.$ ind. $\left.{ }^{-1}\right)$ on kinematic viscosity of seawater, $v\left(\mathrm{~m}^{2} \mathrm{~s}^{-1}\right) / 10^{6}, \mathrm{v}=a+b v$, in groups of fully open mussels, collected at the same locality in different months. Viscosity as a function of temperature is given by Rawson \& Tupper (1968)

\begin{tabular}{|c|c|c|c|c|c|c|c|c|}
\hline \multirow{2}{*}{$\begin{array}{c}\text { No. } \\
\text { of } \\
\text { mussels }\end{array}$} & \multirow{2}{*}{$\begin{array}{c}\text { Size } \\
(\mathrm{mm} \pm \mathrm{SD})\end{array}$} & \multirow[t]{2}{*}{ Month } & \multirow{2}{*}{$\begin{array}{l}\text { Temperature of } \\
\text { acclimatization } \\
\qquad\left({ }^{\circ} \mathrm{C}\right)\end{array}$} & \multirow{2}{*}{$\begin{array}{c}\text { Temperature } \\
\text { range } \\
\left({ }^{\circ} \mathrm{C}\right)\end{array}$} & \multicolumn{3}{|c|}{ Regression parameters } & \multirow{2}{*}{$\begin{array}{c}\text { No. } \\
\text { of } \\
\text { measurements }\end{array}$} \\
\hline & & & & & a & $b$ & r & \\
\hline 25 & $31 \pm 0.7$ & Feb & 6 & $2-16$ & 92.4 & -43.1 & -0.836 & 17 \\
\hline 30 & $29 \pm 2.6$ & Jun & 12 & $4-22$ & 84.9 & -42.8 & -0.951 & 25 \\
\hline 20 & $39 \pm 2.0$ & May & 7.5 & $5-15$ & 120.8 & -52.3 & -0.985 & 4 \\
\hline
\end{tabular}


ing bivalve was made by Loosanoff (1958) on the oyster Crassostrea virginica from Long Island Sound, USA. Pumping rates were measured by the direct method (Loosanoff \& Engle 1947) on 478 oysters, 10 to $11 \mathrm{~cm}$ in length, at temperatures ranging from 0 to $38^{\circ} \mathrm{C}$. Pumping rates were low at temperatures up to $10^{\circ} \mathrm{C}$ and many oysters remained closed or did not pump when open. At temperatures exceeding $16^{\circ} \mathrm{C}$ all oysters opened and pumped water at rates that increased with temperature up to $32^{\circ} \mathrm{C}$. Above $32^{\circ} \mathrm{C}$ the valve gape became unstable and pumping rate declined. The relation between kinematic viscosity $(v)$ and maximum pumping rates (V) within the temperature range 16 to $32^{\circ} \mathrm{C}$ could be described by the equation $\mathrm{V}\left(\mathrm{l} \mathrm{h}^{-1}\right)=$ $27.4-15.2 v(r=-0.72)$. The regression is based on the values listed in Table I in Loosanoff (1958). Pumping rate thus varied inversely with temperaturedependent viscosity. Loosanoff's data from oysters agree closely with those obtained in mussels.

The relationships between filtration rate and temperature in cockles (Cardium edule and C. lamarcki) measured by Brock \& Kofoed (1987) differed from the pattern observed in Mytilus edulis. However, the experiments seem to reflect behaviour under suboptimal conditions, because the cockles filtered at low rates, about an order of magnitude lower than those applying under optimal conditions (Møhlenberg \& Riisgård 1979).

\section{Specific pumping rates}

In order to allow comparisons to be made between mussels of varying size and from different localities,

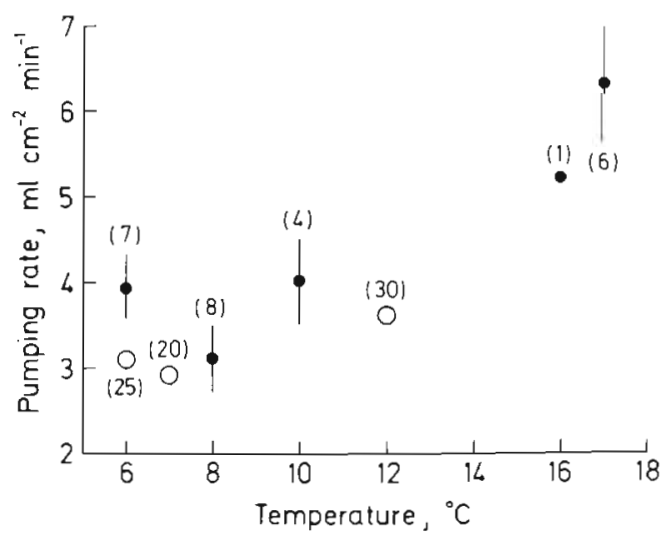

Fig. 4. Mytilus edulis. Flow rate per $\mathrm{cm}^{2}$ gill surface at acclinatization temperatures in nature, measured directly or as algal clearances. Gill areas were measured in experimental specimens or calculated from the relationship between area $A$ $\left(\mathrm{cm}^{2}\right)$ and shell length $\mathrm{L}(\mathrm{cm})$ applying to the population of mussels studied: $\mathrm{A}=1.32 \mathrm{~L}^{1.76}\left(\mathrm{r}^{2}=0.87, \mathrm{n}=45\right.$, size range 1.6 to $6.8 \mathrm{~cm}$ ). ( ) Individual measurements, given as means \pm $\mathrm{SD}_{i}(0)$ measurements on groups of mussels. In parentheses: numbers of individuals pumping rates should be expressed per unit area of the gills. The relative size of the gill surface varies both within and between populations of Mytilus edulis. In Denmark, the relative gill area varies by a factor of about 1.5 between populations, the gills being small in the Wadden Sea and large in the Baltic (Theisen 1982). In mussels from the population sampled in the present study, the relationship between gill area $\mathrm{A}\left(\mathrm{cm}^{2}\right)$ and shell length $L(\mathrm{~cm})$ could be described by the equation $\mathrm{A}=1.32 \mathrm{~L}^{1.75}(\mathrm{r}=0.93 ; \mathrm{n}=45$; size range 1.6 to $6.8 \mathrm{~cm}$ ). This relationship was used to calculate areaspecific pumping rates in experiments where the gill areas were not measured subsequent to determinations of pumping rates. The values obtained did not differ significantly from those in which gill area was measured directly.

Such normalized pumping rates were used to show the annual variation in water processing capacity of mussels at the temperature of acclimatization (Fig. 4). It may be seen that pumping rates obtained in experiments on single individuals ( $\bullet$ ) tended to be higher than means obtained from groups of mussels (o). Individual values were the same whether measured directly in the set-up used to determine pump characteristics or indirectly as algal clearances. The lower values in the groups of from 20 to 30 mussels may therefore be due to insufficient mixing of the water.

A precise temperature effect on specific pumping rates cannot be calculated because of the large scatter in results. However, the data suggests a level of pumping rates of 3 to $4 \mathrm{ml} \mathrm{cm} \mathrm{cm}^{-2} \mathrm{~min}^{-1}$ at about $7^{\circ} \mathrm{C}$, prevailing in May, and about $6 \mathrm{ml} \mathrm{cm} \mathrm{cm}^{-1} \mathrm{~min}^{-1}$ at $17^{\circ} \mathrm{C}$ in August, confirming previous findings of absence of temperature acclimation in water pumping in Mytilus edulis (Jørgensen et al. 1986a). Such acclimation occurred within $14 \mathrm{~d}$ in laboratory experiments by Widdows \& Bayne (1971). In these experiments the mussels were, however, clearing the ambient algal suspension at rates that amounted to only 10 to $30 \%$ of the rates typical of fully open undisturbed mussels (Møhlenberg \& Riisgård 1979).

The large variation between series of experiments in Fig. 4 is striking. Thus, the mean pumping rate at the low temperature of $6{ }^{\circ} \mathrm{C}$, in April, was significantly higher than the mean value obtained in December at an environmental temperature of $8{ }^{\circ} \mathrm{C}(\mathrm{p}<0.01)$. It remains to be seen whether this and other differences are seasonally determined or incidental.

\section{Beat frequencies of lateral cilia: effects of temperature and serotonin}

The finding that variation in pumping rate with temperature could be explained solely by the effect of 
viscosity on the frictional resistance in the canal systems of the pump was unexpected because ciliary activity also varies with temperature. In young, transparent Mytilus edulis, and other bivalves, the mean beat frequency increased from about $10 \mathrm{~Hz}$ at $14^{\circ} \mathrm{C}$, the temperature of acclimatization, to about $15 \mathrm{~Hz}$ or more at 20 to $21^{\circ} \mathrm{C}$, corresponding to $Q_{10}$ values of about 2 (Jørgensen \& Ockelman unpubl).

The activity of the lateral cilia rapidly declines in excised gills or in gill fragments (Gray 1928, Aiello 1960). Presumably, cessation results from interruption of the serotonergic innervation of the gill filaments, and normal beating may be restored by addition of serotonin to the medium (Aiello 1960, Gosselin 1961, Gosselin et al. 1962, Jørgensen 1975b, Catapane et al. 1978). The beat frequency after serotonin stimulation varied with temperature (Catapane et al. 1981). It was therefore of interest to study the temperature dependency of the serotonin-stimulated ciliary activity and to compare it with the temperature dependency of spontaneous activity.

Table 2 shows the effects of temperature and serotonin on beat frequency of the lateral cilia in gill fragments of Modiolus modiolus at the concentrations $10^{-7}, 10^{-6}$ and $10^{-5} \mathrm{M}$. Serotonin at $10^{-7} \mathrm{M}$ restores a normal activity level in isolated gill fragments of Mytilus edulis, whereas $10^{-5} \mathrm{M}$ produces maximum beat frequency (Clemmesen \& Jørgensen 1987). It may be seen that throughout the concentration range the temperature effect was the same, corresponding to a $\mathrm{Q}_{10}=2$.

The effect of serotonin added to the ambient water at $17^{\circ} \mathrm{C}$ was studied at concentrations ranging from $10^{-6}$ to $10^{-4} \mathrm{M}$. The beat frequencies, as measured immediately upon excision of gill fragments (as an approximation to the intact mussel), were $22 \pm 2.1\left(\mathrm{n}=4\right.$ ) at $10^{-6}$ $M$ serotonin, $26 \pm 2.1(\mathrm{n}=8)$ at $10^{-5} \mathrm{M}$ and $26 \pm 1.1$ ( $\mathrm{n}=5$ ) at $10^{-4} \mathrm{M}$. Maximum stimulation was thus obtained at $10^{-5} \mathrm{M}$ serotonin also in 'intact' mussels. The $Q_{10}$ values were of the same order as those measured in the gill fragments of Modiolus modiolus, viz. 2.1

Table 2. Modiolus modiolus. Effects of temperature, $\mathrm{t}$, and serotonin on frequency of beat of the lateral cilia in gill fragments. (Means $\pm \mathrm{SD}$ )

\begin{tabular}{|cccc|}
\hline $\mathrm{t}\left({ }^{\circ} \mathrm{C}\right)$ & $\begin{array}{c}\text { Serotonin } \\
\text { concentration } \\
(\mathrm{M})\end{array}$ & $\begin{array}{c}\text { Beat } \\
\text { frequency } \\
(\mathrm{Hz})\end{array}$ & $\mathrm{Q}_{10}$ \\
\hline 11 & $10^{-7}$ & $10.3 \pm 0.3$ & 2.1 \\
21 & $10^{-6}$ & $21.4 \pm 2.1$ & \\
11 & $10^{-5}$ & $14.0 \pm 1.6$ & 2.0 \\
21 & & $27.5 \pm 2.5$ & \\
11 & & $15.7 \pm 0.3$ & 2.0 \\
21 & & $31.0 \pm 1.5$ & \\
\hline
\end{tabular}

at $10^{-6} \mathrm{M}$ serotonin and 2.3 at $10^{-5} \mathrm{M}$ in the temperature interval 11 to $17^{\circ} \mathrm{C}$, and 1.7 and 1.6 , respectively, in the interval 17 to $21^{\circ} \mathrm{C}$. Thus, the effect of temperature on the activity of the lateral cilia maintained at constant serotonin stimulation, mimicking the normal cilio-excitatory serotonergic innervation, did not differ from the effect on the spontaneous activity in intact mussels.

\section{Levels of interpretation of gill-pump function}

Analytical research at the basic level of the gillpump, the lateral cilia, has revealed that these are under both cilio-excitatory and cilio-inhibitory control, exerted by serotonergic and dopaminergic nerves that terminate in close proximity to the cells carrying the lateral cilia. Extensive pharmacological and electrophysiological evidence has accumulated in support for this nervous control of activity of the lateral cilia (Stefano et al. 1977, Catapane et al. 1978, 1979, 1981, Catapane 1982, Paparo 1985). The functional significance of these complex mechanisms of ciliary control is not clear, because at the level of the intact organism, the output of the activity of the lateral cilia, the pumping of water, turns out to be indifferent to variation in ciliary activity, whether determined by temperature or serotonin stimulation (Jørgensen et al. 1986a).

\section{Pump characteristics}

The effects of temperature on the pump characteristics were studied in April in mussels acclimatized to about $5^{\circ} \mathrm{C}$, the temperature at the collection site. At this time of the year sexually mature Mytilus edulis tend to spawn when heated to temperatures above $12^{\circ} \mathrm{C}$, and the rising temperature induced spawning during the measurements in 3 out of 7 mussels.

Examples of back pressure-pumping rate characteristics in fully open mussels are shown in Fig. 5. The characteristics were detemined at temperatures close to the temperature of acclimatization and at $15^{\circ} \mathrm{C}$, close to the upper limit of the range tolerated. In previous experiments the back pressure-pumping rate characteristics were not found to deviate from linearity. Also, in the present measurements the characteristics were consistently linear at the low temperature. However, in 4 out of 7 mussels they were curved at the high temperature, as shown in Fig. 5b. Such non-linearity was not observed in mussels acclimatized to a high temperature (Jørgensen et al. 1986a). Its importance to the understanding of the pump properties remains to be elucidated.

The characteristics measured in mussels that were spawning at the high temperature did not differ from those in non-spawning individuals. An example is 


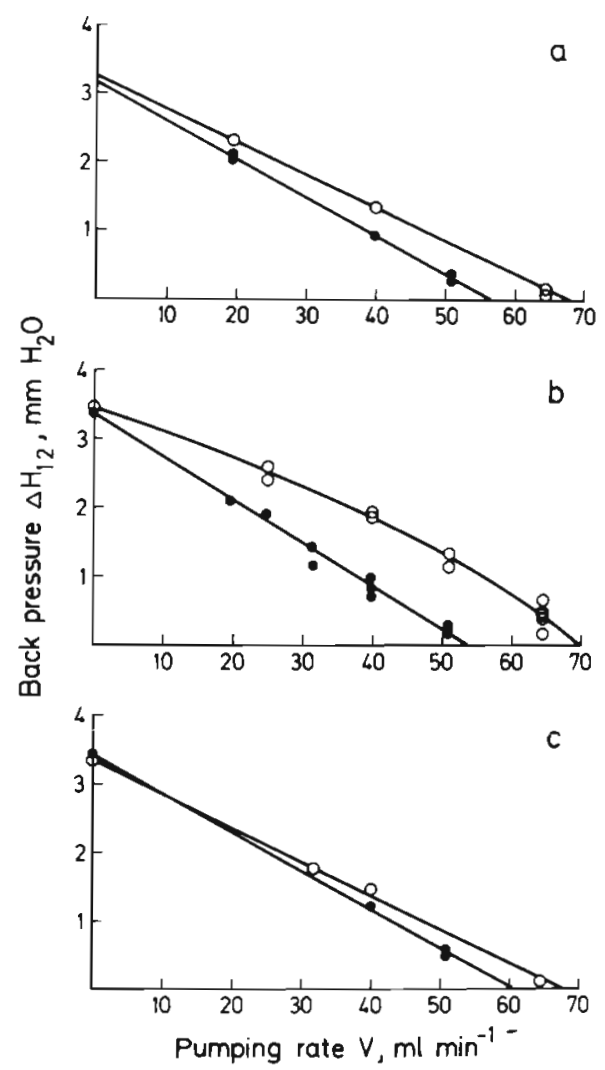

Fig. 5. Mytilus edulis. Three examples of effects of temperature on back pressure-pumping rate characteristics in mussels. (•) 6 to $8{ }^{\circ} \mathrm{C} ;(0) 15^{\circ} \mathrm{C}$. The mussel presented in (C) spawned during measurements at $15^{\circ} \mathrm{C}$ without any obvious

effect on the back pressure-pumping rate relationship

shown in Fig. 5c. This confirms previous observations of mussels spawning in response to an increased temperature. During spawning the gills become leaky to algae, presumably because of the laterofrontal cirri being stopped at the end of their active stroke, and thus removed from the entrance to the interfilament canals, under the influence of increased activity in the serotonergic nervous system (Famme et al. 1986, Jørgensen et al. 1988). The involvement of serotonergic activity in spawning was also indicated in studies of the mussel Mytilus californianus (Smith 1987) and the scallop Patinopecten yessoensis (Matsutani \& Nomura 1987). Because of the concurrent stimulation of the activity of the lateral cilia, the lack of any influence of spawning on the pump characteristic is consistent with the insensitivity of the pump to the activity pattern of the laterofrontal cirri, as well as the beat frequency of the lateral cilia (Jørgensen et al. 1986a, and below).

Maximum pressures at zero pumping, $\Delta \mathrm{H}_{12}^{\circ}\left(=\Delta \mathrm{H}_{\mathrm{p}}^{\circ}\right)$, and maximum pumping rates at zero back pressure, $V^{\circ}$, for all 7 mussels are shown in Table $3 . \Delta \mathrm{H}_{12}^{\circ}$ did not vary with temperature, mean values being $3.15 \pm 0.30$ $\mathrm{mm} \mathrm{H}_{2} \mathrm{O}$ at the low temperature and $3.19 \pm 0.32 \mathrm{~mm}$ $\mathrm{H}_{2} \mathrm{O}$ at the high temperature. In previous experiments on mussels acclimatized to $17^{\circ} \mathrm{C}$ in August and $8^{\circ} \mathrm{C}$ in December, $\Delta \mathrm{H}_{12}^{\circ}$ was slightly, but statistically significantly, higher at the low than at the high temperature (Jørgensen et al. 1986a). The present results, obtained on the same individuals, indicate that the previously found difference was incidental.

Silvester (1988) estimated the maximum pressure exerted by the mussel gill pump under the assumption that the pump unit is the individual lateral cilium. He arrived at the value of $8 \mathrm{~Pa}$, or $0.8 \mathrm{~mm} \mathrm{H}_{2} \mathrm{O}$, i.e. about one fifth of the actually measured pressure produced by fully open mussels at zero flow. It may therefore be concluded that the pump cannot be reduced to the individual cilia and that the pump unit is the opposing oscillating surfaces enveloping the bands of lateral cilia (Brennen \& Winet 1977, Jørgensen et al. 1988).

The effects of temperature on pumping rates (Table 3) showed great individual variation. However, the mean increase in $\mathrm{V}^{\circ}$ with temperature corresponded to the decrease in viscosity, reflected in constancy of the product $v \mathrm{~V}$. These results thus corroborate those

Table 3. Mytilus edulis. Effect of temperature and viscosity, $v\left(\mathrm{~m}^{2} \mathrm{~s}^{-1}\right) / 10^{6}$, on maximum pump pressure, $\triangle \mathrm{H}_{12}^{\circ}$, and pump capacity, $v^{\circ}$, in fully open mussels

\begin{tabular}{|c|c|c|c|c|c|c|c|}
\hline \multirow[t]{2}{*}{ Specimen no. } & \multirow[t]{2}{*}{$\mathrm{L}(\mathrm{mm})$} & \multicolumn{2}{|c|}{$\Delta \mathrm{H}_{12}^{\circ}\left(\mathrm{mm} \mathrm{H}_{2} \mathrm{O}\right)$} & \multicolumn{2}{|c|}{$v^{0}\left(\mathrm{ml} \mathrm{min}^{-1}\right)$} & \multicolumn{2}{|c|}{$v V^{\circ}$} \\
\hline & & $6-8^{\circ} \mathrm{C}$ & $15^{\circ} \mathrm{C}$ & $6-8^{\circ} \mathrm{C}$ & $15^{\circ} \mathrm{C}$ & $6-8^{\circ} \mathrm{C}$ & $15^{\circ} \mathrm{C}$ \\
\hline $1^{\mathrm{a}}$ & 39 & 3.30 & 3.30 & 51 & 76 & 74 & 86 \\
\hline 3 & 37 & 2.90 & 3.00 & 44 & 57 & 64 & 65 \\
\hline $4^{a}$ & 37 & 3.45 & 3.35 & 61 & 68 & 85 & 78 \\
\hline $5^{a}$ & 39 & - & 3.45 & 60 & 80 & 89 & 91 \\
\hline 6 & 38 & 3.30 & 3.45 & 55 & 70 & 75 & 80 \\
\hline 7 & 39 & 3.15 & 3.25 & 56.5 & 68 & 82 & 76 \\
\hline 11 & 39 & 2.65 & 2.55 & 53 & 75 & 79 & 86 \\
\hline \multicolumn{2}{|l|}{$\begin{array}{l}\text { Mean } \\
\pm \mathrm{SD}\end{array}$} & $\begin{array}{r}3.15 \\
\pm 0.30\end{array}$ & $\begin{array}{r}3.19 \\
\pm 0.32\end{array}$ & & & $\begin{array}{c}78 \\
\pm 8.1\end{array}$ & $\begin{array}{c}80 \\
\pm 8.5\end{array}$ \\
\hline \multicolumn{8}{|c|}{ Spawned at $15^{\circ} \mathrm{C}$} \\
\hline
\end{tabular}


obtained in the clearance experiments on groups of mussels.

The independence of the pump characteristic from the beat frequency of the lateral cilia was unexpected, also because it is well established that ciliary-produced water currents vary with the temperature. This has been shown indirectly from the relationship between temperature and velocity of particles suspended in a ciliary-driven current, the particles functioning as indicators of the current velocity. The temperature dependency has been determined for 2 ciliary currents on the mussel gill, the frontal ciliary currents (Gray 1928) and the current in the food groove along the ventral margin of the demibranchs (Jørgensen 1975b). The $Q_{10}$ values were in the order of 2 to 3 , similar to those applying to the ciliary activity. A similar temperature dependency presumably also applies to the water currents produced by the individual band of lateral cilia on an isolated gill filament. It is therefore indicated that its absence in the gill is a consequence of the apposition of gill filaments. However, the mechanism involved remains to be elucidated.

\section{Pump model}

As the detailed fluid mechanics of the mussel gill pump so far is not available, a phenomenological pump model is proposed. The approach in the analysis of pump and system characteristics is the same as in previous papers (Jørgensen et al. 1986a, 1988). The operating point is determined by equating pump characteristic and system characteristic, $\Delta H_{p}=\Delta H_{s}$ (Fig. 1). The system characteristic is calculated as the sum of the major contributions, including friction in the interfilament canals, $\Delta \mathrm{H}_{1 \mathrm{fc}}$ and in the exhalant siphon, $\Delta H_{e s}$ as well as the kinetic energy loss in the jet current leaving the siphon, $\Delta \mathrm{H}_{\mathrm{ex}}$, and the imposed back pressure, $\Delta \mathrm{H}_{12}$,

$$
\Delta \mathrm{H}_{\mathrm{s}}=\Delta \mathrm{H}_{\mathrm{ifc}}+\Delta \mathrm{H}_{\mathrm{es}}+\Delta \mathrm{H}_{\mathrm{ex}}+\Delta \mathrm{H}_{12} .
$$

The frictional and kinetic components were calculated from

$$
\begin{gathered}
\Delta \mathrm{H}_{\mathrm{ifc}}=12 v \mathrm{Lv} /\left(g \ell^{2}\right) \approx v \mathrm{~V} \\
(\text { Schlichting 1968, p. } 125-131) \\
\Delta \mathrm{H}_{\mathrm{es}}=2.66\left(v \mathrm{v}^{3} \mathrm{~L}\right)^{1 / 2} /(\mathrm{d} g) \sim v^{1 / 2} \mathrm{~V}^{3 / 2}, \\
\Delta \mathrm{H}_{\mathrm{ex}}=\text { const. } \mathrm{v}^{2} / 2 g \sim \mathrm{V}^{2}
\end{gathered}
$$

where $v=$ kinematic viscosity; $L=$ length of the interfilament canals or the exhalant siphon; $\mathrm{v}=$ mean velocity; $g=$ acceleration of gravity; $\ell=$ distance between adjacent filaments; $\mathrm{V}=$ pumping rate; $\mathrm{d}=$ hydraulic diameter of the siphon $(3.3 \mathrm{~mm}$ ) (Jørgensen et al. 1986a).

Eqs. (5) and (6) for $\Delta H_{e s}$ and $\Delta H_{e x}$ are approxima- tions, disregarding boundary layers developed along the walls of the siphon, thus increasing core velocities (Jørgensen et al. 1986a). Considering other uncertainties in the dimensioning of the pump geometry, as well as the relatively small variations in viscosity, the simplified scaling of these components in Eq. (3) seems justified.

The leaky, viscous gill pump may be modelled phenomenologically as

$$
\mathrm{V}=\mathrm{V}_{\mathrm{d}}-\mathrm{V}_{\mathrm{i}}
$$

the net volume flow $V$ (= pumping rate) being the difference between the driven volume flow $V_{d}$ and the flow $V_{t}$ leaking back through the pump. The latter, assuming developed viscous flow and fixed geometry, satisfies a relation like Eq. (4) in terms of the pressure rise over the pump, hence

$$
v_{\ell} \approx \Delta H_{p} / v \text {. }
$$

The former, as discussed above, is modelled according to a time-averaged constant force-driven viscous flow, hence

$$
\mathrm{V}_{\mathrm{d}} \approx 1 / \mathrm{v}
$$

From Eqs. (7) to (9) emerges the pump characteristic for fixed geometry. This may conveniently be written in terms of reference values, as

$$
\Delta H_{p}=\Delta H_{p}^{\circ}\left(1-\frac{v V}{v_{r} V_{p r}^{o}}\right) .
$$

$\Delta \mathrm{H}_{\mathrm{p}}^{\circ}$ denotes the maximum pressure at zero pumping, a measurable quantity equal to $\Delta \mathrm{H}_{12}^{\circ}$; subscript $\mathrm{r}$ refers to values at a reference temperature, $t_{r i}$ and $V_{p r}^{o}$ denotes the pumping rate at zero pump back-pressure, a quantity to be inferred.

Calculations have been made for a standard mussel of $35 \mathrm{~mm}$ in shell length, using $t_{\mathrm{r}}=17^{\circ} \mathrm{C}$ as the reference temperature. The standard pumping rate is taken to be $\mathrm{V}_{\mathrm{r}}=65 \mathrm{ml} \mathrm{min}^{-1}$, corresponding to a gill area of $12 \mathrm{~cm}^{2}$ and adopting a conservative estimate of the area-specific pumping rate (Fig. 4). This value of $V_{r}$ at $17^{\circ} \mathrm{C}$ is slightly higher than the value of $60 \mathrm{ml} \mathrm{min}^{-1}$ used previously (Jorgensen et al. 1986a). However, it is recognized that individual variation in pumping rate is large. The standard chosen therefore reflects a level within a range of potential pumping rates, rather than a well-defined population mean.

Frictional and kinetic components to pressure drop, calculated from Eqs. (4) to (6) for the pumping rate $V_{x}$ (following Jørgensen et al. 1986a), are listed in Table 4 at $\mathrm{t}_{\mathrm{I}}=17^{\circ} \mathrm{C}$. Using these values the system characteristic (Eq. 3) may be written

$$
\begin{aligned}
\Delta \mathrm{H}_{\mathrm{s}}= & 0.34 \frac{v \mathrm{~V}}{v_{\mathrm{r}} \mathrm{V}_{\mathrm{r}}}+0.18\left(\frac{v}{v_{\mathrm{r}}}\right)^{1 / 2}\left(\frac{\mathrm{V}}{\mathrm{V}_{\mathrm{r}}}\right)^{3 / 2} \\
& +0.44\left(\frac{\mathrm{V}}{\mathrm{V}_{\mathrm{r}}}\right)^{2}+\Delta \mathrm{H}_{12}
\end{aligned}
$$


Table 4. Mytilus edulis. Pumping rate and predominant head losses in an optimally pumping $35 \mathrm{~mm}$ standard mussel at the reference temperature, $t_{r}$ of 17,10 and $5^{\circ} \mathrm{C}$, calculated from a viscous, leaky, constant-force pump model

\begin{tabular}{|lccc|}
\hline Temperature $\left({ }^{\circ} \mathrm{C}\right)$ & 17 & 10 & 5 \\
$\nu / v_{\mathrm{r}}\left(v_{\mathrm{r}}=1.129 \times 10^{-6} \mathrm{~m}^{2} \mathrm{~s}-\mathrm{l}\right)$ & 1.0 & 1.20 & 1.38 \\
Pumping rate $\mathrm{V}\left(\mathrm{ml} \mathrm{min} \mathrm{min}^{-1}\right)$ & 65 & 56.84 & 50.67 \\
Head losses $\triangle \mathrm{H}\left(\mathrm{mm} \mathrm{H} \mathrm{H}_{2} \mathrm{O}\right)$ & & & \\
$\quad \begin{array}{l}\text { Frictional losses } \\
\quad \text { Interfilament canals } \Delta \mathrm{H}_{\mathrm{ifc}}\end{array}$ & 0.34 & 0.356 & 0.366 \\
$\quad \begin{array}{l}\text { Exhalant siphon } \triangle \mathrm{H}_{\mathrm{es}} \\
\text { Kinetic loss } \\
\quad \text { Exhalant siphon } \triangle \mathrm{H}_{\mathrm{ex}}\end{array}$ & 0.18 & 0.161 & 0.146 \\
$\quad 0.44$ & 0.336 & 0.267 \\
$\quad$ Total losses & 0.96 & 0.85 & 0.78 \\
\hline
\end{tabular}

where $v_{\mathrm{r}}=1.129 \times 10^{-6} \mathrm{~m}^{2} \mathrm{~s}^{-1}$ is the kinematic viscosity of $35 \%$ seawater (Wheaton 1977); $V_{r}=65.0 \mathrm{ml} \mathrm{min}^{-1}$ is the pumping rate of the standard mussel, both applying at the reference temperature $t_{\mathrm{r}}=17^{\circ} \mathrm{C}$.

Finally, equating Eqs. (10) and (3a) gives, for any specified back pressure and temperature (hence viscosity), the operating point in terms of pumping rate $\mathrm{V}$ and pressure $\Delta \mathrm{H}\left(=\Delta \mathrm{H}_{\mathrm{p}}=\Delta \mathrm{H}_{\mathrm{s}}\right)$. Specifically, for $\mathrm{V}=$ 0 , this gives $\Delta \mathrm{H}_{\mathrm{p}}^{\circ}=\Delta \mathrm{H}_{12}^{\circ}$, which is taken to be $3.3 \mathrm{~mm}$ $\mathrm{H}_{2} \mathrm{O}$ for the standard mussel (cf. Table 3 and Jørgensen et al. 1986a, 1988). Also, for $\Delta H_{12}=0$ and $V=V_{r}$, the equality of Eqs. (10) and (3a) determines the inferred pump parameter to $\mathrm{V}_{p r}^{\circ}=91.67 \mathrm{ml} \mathrm{min}^{-1}$, such that the pump characteristic (Eq. 10) becomes

$$
\Delta H_{\mathrm{p}}=3.3\left(1-\frac{v}{v_{\mathrm{r}}} \frac{\mathrm{V}}{91.67}\right) .
$$

System characteristics, $\Delta \mathrm{H}_{\mathrm{s}}(\mathrm{V})$ for $\Delta \mathrm{H}_{12}=0$, and pump characteristics, $\Delta \mathrm{H}_{\mathrm{p}}(\mathrm{V})$, have been calculated from Eqs. (3a) and (10a) at the reference temperature

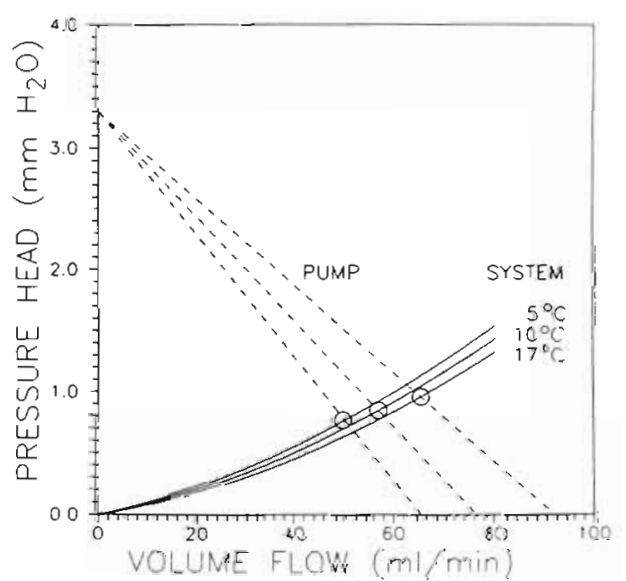

Fig. 6. Mytilus edulis. System and pump characteristics at 3 temperatures, the reference temperature $17^{\circ} \mathrm{C}$, and 10 and $5^{\circ} \mathrm{C}$, as calculated from equations modelling the mussel as a viscous, leaky, constant-force pump. See text for further explanation $17^{\circ} \mathrm{C}$, as well as at 10 and $5^{\circ} \mathrm{C}$ (Fig. 6). The operating points and pumping rates at zero back pressure are derived by equating $\Delta \mathrm{H}_{\mathrm{p}}=\Delta \mathrm{H}_{\mathrm{s}}$ for $\Delta \mathrm{H}_{12}=\mathrm{O}$ and solving for $\mathrm{V}$ and $\Delta \mathrm{H}$. The results of the calculations are shown in Table 4.

It may be seen that the pumping rate $V\left(\mathrm{ml} \mathrm{min}^{-1}\right)$ at the operating point declines moderately with decreasing temperature $\left({ }^{\circ} \mathrm{C}\right)$, approximately as $\mathrm{V}=44.8+1.19$ $\mathrm{t}$, or, in terms of kinematic viscosity $\left(10^{-6} \mathrm{~m}^{2} \mathrm{~s}^{-1}\right)$, as $\mathrm{V}$ $=102.5-33.4 v$. The latter expression may be compared to regression parameters in Table 1 . The agreement is reasonable in view of the fact that the models of pump and system have not been derived directly from the data.

The agreement between measured and estimated gill pump parameters and predictions of the viscous, leaky, constant-force pump model further supports the concept of the mussel and other filter-feeding bivalves as filter-pumps that process the ambient water autonomously, that is, in the absence of physiological mechanisms for regulating water pumping (Jørgensen et al. 1986a, b, 1988).

Acknowledgement. We thank an anonymous referee for valuable comments and suggestions which substantially improved the paper.

\section{LITERATURE CITED}

Aiello, E. L. (1960). Factors affecting ciliary activity on the gill of the mussel Mytilus edulis. Physiol. Zool. 33: 120-135

Borchardt, T (1985). Relationship between carbon and cadmium uptake in Mytilus edulis. Mar. Biol. 85: 233-244

Brennen, C., Winet, H. (1977). Fluid mechanics of propulsion by cilia and flagella. Ann. Rev. Fluid Mech. 9: 339-398

Brock, V., Kofoed, L. H. (1987). Species specific irrigatory efficiency in Cardium (Cerastoderma) edule (L.) and C. lamarcki (Reeve) responding to different environmental temperatures. Biol. Oceanogr. 4: 211-226

Catapane, E. (1982). The peripheral innervation of the gill of the marine mollusc demonstrated by the aluminium-formaldehyde (ALFA) histofluorescence method. Cell Tissue Res. 225: 449-454

Catapane, E. J., Stefano, G. B., Aiello, E. (1978). Pharmacological study of the reciprocal dual innervation of the lateral ciliated gill epithelium by the CNS of Mytilus eduirs (bivalvia). J. exp. Biol. 74: 101-113

Catapane, E. J., Stefano, G. B., Aiello, E. (1979). Neurophysiological correlates of the dopaminergic cilio-inhibitory mechanism of Mytilus edulis. J. exp. Biol. 83: 315-323

Catapane, E. J., Thomas, J. A., Stefano, G. B., Paul, D. F. (1981). Effects of temperature and temperature acclimation on serotonin-induced cilio-excitation of the gill of Mytilus edulis. J. therm. Biol. 6: 61-64

Clemmesen, B., Jorgensen, C. B. (1987). Energetic costs and efficiencies of ciliary filter feeding. Mar. Biol. 94: 445-449

Epifania, E. C., Ewart, J. (1977). Maximum ration of four diets for the oyster Crassostrea virginica Gmelin. Aquaculture 11: $13-29$

Famme, P., Riisgård, H. U., Jørgensen, C. B. (1986). On direct measurements of pumping rates in the mussel Mytilus edulis. Mar Biol. 92: 323-327 
Gerdes, D. (1983). The pacific oyster Crassostrea gigas. Part 1 Feeding behaviour of larvae and adults. Aquaculture 31: 195-219

Gosselin, R. E. (1961). The cilio-excitatory activity of serotonin. J. Cell. Comp. Physiol. 58: 17-26

Gosselin, R. E., Moore, K. E., Milton, A. S. (1962). Physiological control of molluscan gill cilia by 5-hydroxytryptamine. J. gen. Physiol. 46: 277-296

Gray, J. (1928). Ciliary movement. Cambridge University Press, London

Jørgensen, C. B. (1975a). Comparative physiology of suspension feeding. Ann. Rev. Physiol. 37: 57-79

Jorgensen, C. B. (1975b). On gill function in the mussel Mytilus edulis L. Ophelia 13: 187-232

Jorgensen, C. B., Famme, P., Kristensen, H. S., Larsen, P. S., Møhlenberg, F., Riisgård, H. U. (1986a). The bivalve pump. Mar. Ecol. Prog. Ser. 34: 69-77

Jørgensen, C. B., Larsen, P. S., Møhlenberg, F., Riisgård, H. U. (1988). The mussel pump: properties and modelling. Mar. Ecol. Prog. Ser. 45: 205-216

Jørgensen, C. B., Møhlenberg, F., Sten-Knudsen, O. (1986b). Nature of relation between ventilation and oxygen consumption in filter feeders. Mar. Ecol. Prog. Ser. 29: 73-88

Kiørboe, T., Møhlenberg, F., Nohr, O. (1981). Effect of suspended bottom material on growth and energetics in Mytilus edulis. Mar. Biol. 61: 283-288

Loosanoff, V L. (1958). Some aspects of behavior of oysters at different temperatures. Biol. Bull. mar. biol. Lab., Woods Hole 114: 57-70

Loosanoff, V. L., Engle, J. B. (1947). Effect of different concentrations of micro-organisms on the feeding of oysters $(O$. virginica). US Fish Wildl. Serv. Bull. 51: 31-57

Matsutani, T., Nomura, T (1987). In vitro effects of serotonin and prostaglandins on release of eggs from the ovary of the scallop, Patinopecten yessoensis. Gen. comp. Endocrinol. 67: 111-118

Møhlenberg, F., Riisgård, H. U. (1978). Efficiency of particle retention in 13 species of suspension feeding bivalves. Ophelia 17: $239-246$

Mohlenberg, F., Riisgård, H. U. (1979). Filtration rate, using a new indirect technique, in thirteen species of suspension feeding bivalves. Mar. Biol. 54: 143-148

Newell, R. C., Bayne, B. L. (1980). Seasonal changes in the physiology, reproductive condition and carbohydrate content of the cockle Cardium (Cerastoderma) edule (Bivalvia: Cardiidae). Mar. Biol. 56: 11-19

This article was submitted to the editor
Palmer, R. E. (1980). Behavioral and rhythmic aspects of filtration in the bay scallop. Argopecten irradians concentricus (Say), and the oyster, Crassostrea virginica (Gmelin). J. exp. mar. Biol. Ecol. 45: 273-295

Paparo, A. A. (1985). The role of the cerebral and visceral ganglia in ciliary activity. Comp. Biochem. Physiol. 81A: $647-651$

Rawson, K. J., Tupper, E. C. (1968). Basic ship theory. American Elsevier, New York

Riisgård, H. U., Poulsen, E. (1981). Growth of Mytilus edulis in net bags transferred to different localities in a eutrophicated Danish fjord. Mar. Pollut. Bull. 12: 272-276

Riisgård, H. U., Randlov, A. (1981). Energy budgets, growth and filtration rates in Mytilus edulis at different algal concentrations. Mar. Biol. 61: 227-234

Schlichting, H. (1968). Boundary layer theory, 6th edn. McGraw-Hill Inc., New York

Silvester, N. R. (1988). Hydrodynamics of flow in Mytilus gills. J. exp. mar. Biol. Ecol. 120: 171-182

Smith, J. R. (1987). The role of the nervous system in algaeinduced gamete release by Mytilus californianus. Comp. Biochem. Physiol. 86C: 215-218

Sprung, M., Rose, U. (1988). Influence of food size and food quantity on the feeding of the mussel Dreissena polymorpha. Oecologia (Berl.) 77: 526-532

Stefano, G. B., Catapane, E. J., Stefano, J. M. (1977). Temperature dependent ciliary rhythmicity in Mytilus edulis and the effects of monoaminergic agents on its manifestation. Biol. Bull. mar biol. Lab., Woods Hole 153: $618-629$

Theisen, B. F. (1982). Variation in size of gills, labial palps, and adductor muscle in Mytilus edulis L. (bivalvia) from Danish waters. Ophelia 21, 49-63

Wheaton, F. W. (1977). Aquacultural engineering. Wiley, New York

Widdows, J., Bayne, B. L. (1971). Temperature acclimation of Mytilus edulis with reference to its energy budget. J. mar. biol. Ass. U.K. 51: 827-843

Winter, J. E. (1973). The filtration rate of Mytilus edulis and its dependence on algal concentration, measured by a continuous automatic recording apparatus. Mar. Biol. 22: $317-328$

Winter, J. E., Acevedo, M. A., Navarro, J. M. (1984). Quempillén estuary, an experimental oyster cultivation station in southern Chile. Energy balance in Ostrea chilensis. Mar. Ecol. Prog. Ser. 20: 151-164

Manuscript first received: November 30, 1989

Revised version accepted: April 10, 1990 